Int. J. Speleol. 10 (1978), pp. 3 - 9

\title{
A Classification of Karstic Phenomena
}

\author{
by
}

\author{
ARRIGO A. CIGNA
}

According to the usual attitude to establish schemes into which the natural phenomena could be enlisted, caves and phenomena related to them are also considered under this point of view. Anyway it must remembered that classifications are artificial tools: I recall here the words of professor Gortani «classifications don't exist in nature, they are a product of our mind when we wish to make the knowledge, the description and the nomenclature of features easier» (Gortani, 1933).

Speleology is a typical interdisciplinary science and for reasons of coherence it is convenient to achieve a uniformity of language with the bordering sciences. Such a concordance is quite fundamental to avoid any misundertanding when the same phenomenon is to be considered from different approaches.

At present it is not necessary to recall here all the systems proposed for the classificatiom of karstic phenomena. It is sufficient to remember that cave morphology and some rock parameters, like solubility by the percolating waters, played an important role in the rationale of these classification (Floridia, 1941; Kosack, 1952; Anelli 1957-58, 1963, 1973; Halliday, 1960; Kipiani, 1974; Tell, 1976).

As it is well expressed by the Latin «qui incipit numerare incipit errare» (= who begins to make a list, he begins to make faults) some criticism can be made to such systems. Now there is no intention at all to propose another way to classify karstic phenomena, but to introduce a closer view of the problem. In fact it appears evident that the effective processes responsible for caves formation, more than morphological analogies, should be taken into account.

Any classification based on the rock solubility would imply the definition of limits between classes: it is easy to foresee that an agreement on the values of such limits would be nearly impossible to obtain. On the other hand any classification related to rock solubility but based on the morphological features of the phenomena, as it was recently proposed by Forti et al. (1977) is interesting and rather useful on a local basis but it cannot be adopted by attributing to it an absolute value. 
Thus, a different approach should be envisaged to guarantee a subdivision into classes as non arbitrary as practicable.

Let the physical-chemistry of the karstic phenomena be considered. As it is wellknown the solution of calcium carbonate is determined by a threecomponents equilibrium. These components are calcium carbonate, water and carbon dioxide.

Therefore it is obvious that such a solution process is quite different from another one arising from a two-components equilibrium (as it happens, e.g. for gypsum and water) or from a totally different mechanism (e.g. eolic caves or gas-filled cavities within fluid lava).

Then it can be inferred that the number of the components in a given system is suitable to be adopted as the parameter to identify a class. If such a philosophy is accepted, the karstic phenomena latu sensu, (i.e. in the broader meaning of the term) can be classified in some main classes according to the process prevalent in each case:

I) more than three-components phase equilibria.

II) three-components phase equilibria.

III) two-componets phase equilibria.

IV) one-component phase equilibria.

V) no phase equilibria (in the chemical meaning of the term).

A closer examination of these classes may be useful to a better understanding of this kind of classification.

For sake of simplicity, as it is more evident further on, the first class will be considered later. It was pointed out before that the solution of limestone is obviously considered into the second class: therefore these kinds of processes can be classified as karstic phenomena.

Examples of two-components phase equilibria are the solutions of gypsum and quartzite in water (this is generally correct: see appendix). Of course the development of the processes will take very different time intervals on account of the high solubility of gypsum and the low one of quartzite. Nevertheless it must be pointed out that the same kind of equilibrium is present in both cases. These processes which concern phase equilibria with two components only could be classified as parakarstic phenomena. In fact they have some similarity with the karstic phenomena leading also to some morphological analogies. Water (ice) and lava are the only examples (at least to the present knowledge) of one-component phase equilibria. The results of these processes are still similar to the true karstic forms notwithstanding a conceptual difference in the essence of the phenomenon. For this reason the term of hypokarstic phenomena is here proposed when only one component is involved in the phase equilibria.

In this frame of classification, the phase equilibria with more than components, i.e. those considered in the first class of the present list, could be defined as hyperkarstic phenomena. Such phenomena are generally rare and may 
be found in some peculiar sites (e.g. in the vicinity of hydrothermal springs) when solutions rich of different compounds are present.

Any process not bound to a phase equilibrium could eventually be included in the last class of the classification here proposed or when limestone and gypsum can be found together.

Therefore, tectonic cavities, gas-filled lava cavities, erosion due to wind or water action, could be considered pseudokarstic phenomena. It must be emphasized that the only connection of such phenomena with the karstic ones is purely morphological, while the mechanisms of formation and development are completely different.

The five main classes here proposed may be further divided into subclasses, taking into account some relevant features. Therefore the definitions of holokarst and merokarst given by Cvijic (1960) fit quite suitably. (Holokarst: c'est le Karst complet dans lequel toutes les formes karstiques sont parfaitement développées ainsi que les phénomènes les plus variés de l'hydrographie souterraine; mérokarst: dans celui-ci ne sont développés que certain traits du relief karstique, d'autres manquent complètement ou sont considérablement modifiés: c'est donc un karst partiel et imparfait). More recently Maximovitch (1975) used the adjectives «brady» and "tachy» to distinguish the karstic phenomenon in low-solubility and high-solubility rocks respectively.

Such terms seem to be rather appropriate and could be retained for a further subdivision of the parakarstic phenomena to take into account the different characteristics of the rocks affected by parakarstic process.

The class of pseudokarstic phenomena could be eventually divided into subclasses according to the cavity development concomitant with the rock formation (syngenetic pseudokarst: e.g. gas-filled lava cavities) or successive to it (epigenetic pseudokarst: e.g. tectonic caves, erosion caves).

The classification here proposed is summarized in Table 1. Its advantages are the coherence with the physical-chemistry terminology, the lack of arbitrary limits between classes and the capability to accept further subdivisions if they will be needed in future.

Table 1

CLASSIFICATION OF THE KARSTIC PHENOMENA

\begin{tabular}{|c|c|c|c|}
\hline Class & $\begin{array}{c}\text { Phase } \\
\text { equilibria } \\
\text { N. of comp. }\end{array}$ & Sub-class & Examples \\
\hline Hyperkarst & $>3$ & - & Special hydrothermal environments. \\
\hline Karst & 3 & $\begin{array}{l}\text { Holokarst } \\
\text { Merokarst }\end{array}$ & $\begin{array}{l}\text { Pure limestone. } \\
\text { Dolomite, marly limestone. }\end{array}$ \\
\hline Parakarst & 2 & $\begin{array}{l}\text { Brady } \\
\text { Tachy }\end{array}$ & $\begin{array}{l}\text { Quartzite, tufa. } \\
\text { Gypsum, rock-salt. }\end{array}$ \\
\hline Hypokarst & 1 & - & Ice, lava flow tubes. \\
\hline Pseudokarst & 0 & $\begin{array}{l}\text { Syngenetic } \\
\text { Epigenetic }\end{array}$ & $\begin{array}{l}\text { Gas-filled lava cavities. } \\
\text { Tectonic caves, erosion caves. }\end{array}$ \\
\hline
\end{tabular}




\section{Acknowledgements}

I am indebted to Giulio Cappa for his original idea to classify karstic phenomena according to the corresponding phase equilibria. I am also grateful to many friends and colleagues who helped me to develop these criteria with fruitful discussions and, last but not the least, to Miss Marjorje Sweeting for the review of the English text.

\section{REFERENCES}

G.B. ALEXANDER, W.M. HESTON, R.K. ILER, 1954 - The solubility of amorphous silica in water J. Phys. Chem., 58:453/455.

G.M. ANDERSON, 1972 - Silica Solubility, in: R.W. FAIRBRIDGE (Ed.) - The Encyclopedia of Geochemistry and Environmental Sciences. Van Nostrand Reinhold Co., 4A: 1085/1088.

F. ANELLI, 1957-1958 - Nomenclatura italiana dei fenomeni carsici. Le Grotte d'Italia, Bologna, s3, 2:5/36.

F. ANELLI, 1963 - Fenomeni carsici, paracarsici e pseudocarsici. Giorn. di geologia, Bologna, s2, 31:11/25.

F. ANELLI, 1973 - Nuove osservazioni sui fenomeni carsici, paracarsici e pseudocarsici. Le Grotte d'Italia, Bologna, s.4, 4:165/198.

A. BÖGLI, 1960 - Kalklösung und Karrenbildung. Zeitschr. Geomorph., Suppl. 2, Karstmorphologie: $4 / 21$.

K.C. CONDIE, 1972-74 - Silicon (14-F, G, H and I), in: K.H. WEDEPOHL (Ed.) - Handbook of Geochemistry, Springer-Verlag, 2 (3) (4).

J. CVIJIC, 1960 - La géographie des terrains calcaires. Monographies Acad. Serbe Sc. et Arts, CCCXLI, Cl. Sc. Math. Nat., n. 26, Beograd: 141/207.

M. DALL'AGLIO, 1968 - Distribution and circulation of the major and some trace elements in surface waters of Italy. Int. Ass. Sc. Hydrology, Berna, 78:79/91.

P. DUCHAUfour, 1965 - Precis de Pédologie. Masson \& Cie., Paris.

G.B. FLORIDIA, 1941 - Un particolare fenomeno pseudocarsico manifestato da alcune argille. Boll. Soc. Sc. Nat. Econ., Palermo, 23:12.

F. FORTI, S. STEFANINI, F. ULCIGRAI, 1974 - Relazioni fra solubilità e carsificabilità nelle rocce carbonatiche del Carso triestino. Att. e Mem. Commiss. Grotte «E. Boegan», Trieste, 14:19/49.

M. GORTANI, 1933 - Per lo studio idrologico e morfologiche delle regioni carsiche e semicarsiche italiane. Att. I Congr. Speleol. Naz., Trieste: 109/115.

W.R. HALlidAY, 1960 - Pseudokarst in the United States. Bull. Natl. Spel. Soc., Arlington (Virginia), 22(2): 109/113.

C. KIPIANI, 1974 - (The Karst of Georgia) (in Georgian). Metsniereba, Tbilissi, 1:193/196. H.P. KOSACK, 1952 - Die Verbreitung der Karst - und Pseudokarsterscheinungen über die Erde. Petermans Geogr. Mitt., 96(1):16/22.

G. KIRLE, 1923 - Grundriss der theoretischen Speläologie. Öst. Staatsdruckerei, Wien:15/31. M.E. MARKER, 1976 - Note on some South African pseudokarst. Bol. Soc. Venezolana Espel., Caracas, 7(13):5/12.

G.A. MAXIMOVITCH, 1975 - (On the brady-karst in the tropical zone) (in Russian). Gidrogeologija $i$ karstoved, Perm, 7:5/14.

E. SZCZERBAN, F. URBANI, 1974 - Carsos de Venezuela. Parte 4: Formas carsicas en areniscas precambricas del Territorio Federal Amazonas y Estado Bolivar. Bol. Soc. Venezolana Espel., Caracas, 5(1):27/54.

L. TELL, 1976 - About karst in general and Swedish karst in particular Proc. 6th Int. Congr. Speleol., Olomouc 1973, 2:381/407.

D.E. WHITE, WW. BRANNOCK, K.J. MURATA, 1956 - Silica in hot spring waters. Geochim. Cosmochim. Acta, 10:27/59.

W.B. WHITE, G.L, JEFFERSON, J.F. HAMAN, 1966 - Quartzite Karst in Southeastern Venezuela. Int. J. Speleol., Lehre, 2(4):309/314. 


\section{APPENDIX}

\section{The solubility of silica in water.}

Recently the attention of cavers was called by the exploration of important caves systems in quartz sandstones (Szczerban and Urbani, 1974). It becomes rather evident that complex cave systems may develop in rocks usually considered insoluble.

In order to take in the due consideration this kind of phenomena to the purpose of classification, it was necessary to study the factors affecting the solubility of silica.

In some chemical handbooks silica is reported to be insoluble in water and very slightly soluble in alkali. It was also postulated that the deep weathering of siliceous rocks might be related to a period of alkaline hydrolysis (Duchaufour, 1965; Marker, 1976).

If the solution of siliceous rocks would be influenced by the $\mathrm{pH}$ of the meteoric or the percolating water, the process should be included in the class of karstic phenomena (three-components phase equilibria). But a study of the silica geochemistry pointed out that the solubilities of all $\mathrm{SiO}_{2}$ polymorphs are virtually independent (Fig. 1) of the concentrations of dissolved salts and of the $\mathrm{pH}$ of aqueous solutions up to nearly $\mathrm{pH} 9$ (Alexander et al., 1954; Anderson, 1972; Condie, 1972-74). The rate of dissolution, only, is strongly affected by $\mathrm{pH}$ : at $\mathrm{pH}$ values below 5 the dissolution process is very slow and may take months, where at $\mathrm{pH} 8$ the gel may dissolve to saturation overnight (Condie, 1972-74).

This fact may explain perhaps few anomalous results obtained in the past by some researchers ans, on the other hand, let the percolating waters have a certain degree of aggressiveness which is responsible of cavern development in some particular instances: i.e. at a certain depth below the ground surface. In fact in the case of two components process the «Boegli effect» due to the mixture of waters cannot exist and therefore cannot contribute to the formation of cavities as in the case of a karstic process. The unique variable affecting the equilibrium in the solution of silica is temperature as it is reported in fig. 2 (Alexander, 1954; Anderson, 1972). Due to the paucity of experimental results the curve for chalcedony should be considered as a zone of uncertain width rather than a line.

The solubility of silica polymorphs varies within a rather wide range (over an order of magnitude between quartz and amorphous silica). Therefore the behaviour in weathering of the silicates corresponds well with their abundance as detritus. The less soluble silica, quartz, is almost the sole constituent of the most mature detritus, the quartz-rich sandstones.

The dissolved silica concentrations in groundwaters range between a few ppm to almost $100 \mathrm{ppm}$ (Condie, 1972-74). An estimate of the concentrations to be found in a temperature region is given by the analysis of over 5000 samples of surfaces waters in Italy. An average value of $11 \mathrm{ppm}$ with a standard deviation of $10 \mathrm{ppm}$ was obtained (Dall'Aglio, 1968). In hot springs the waters tend to 


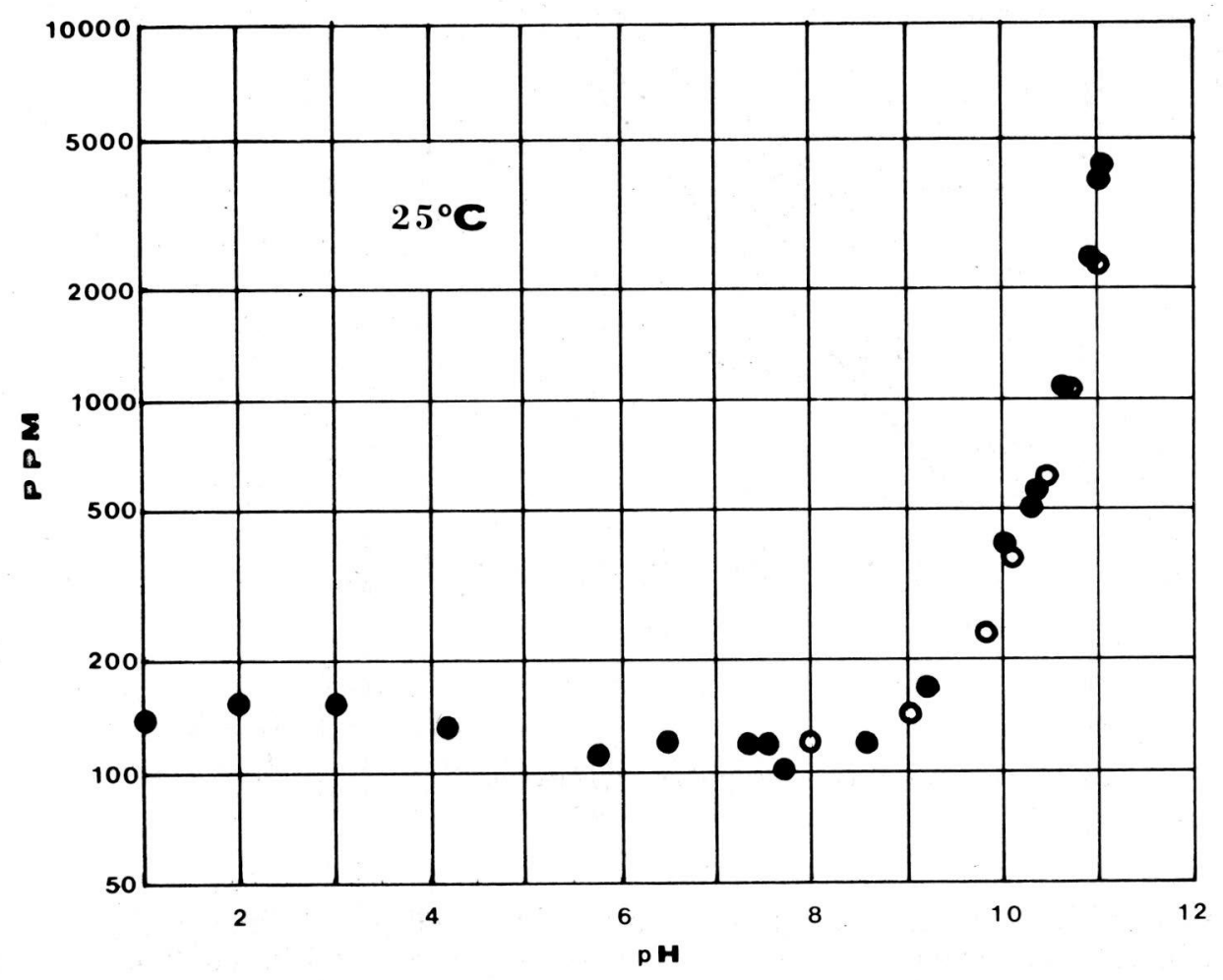

Fig. 1 - Solubility of silica as a function of the $\mathrm{pH}$. 


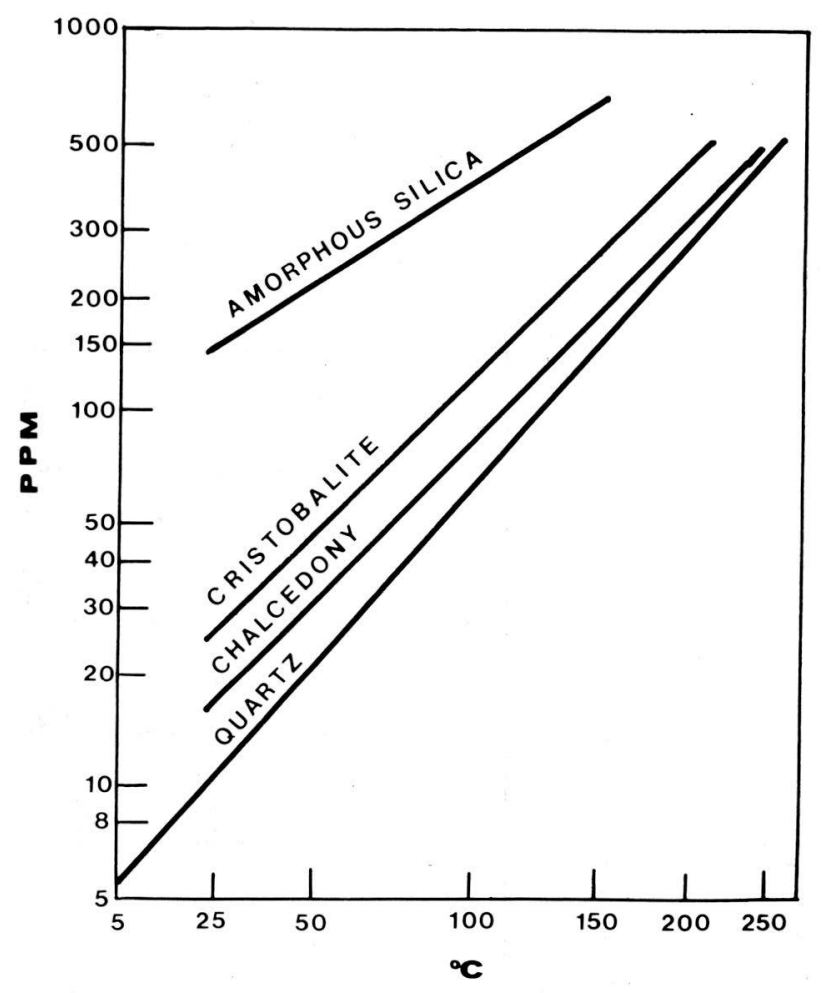

Fig. 2 - Solubility of silica polymorphs as a function of the temperature.

have rather high silica concentrations up to almost $400 \mathrm{ppm}$ (White et al., $1956)$, i.e. values higher than those commonly measured for calcium in limestone.

As it was pointed out by Bögli (1960) in particular conditions or when the process is allowed to develop during a long time interval, important cave system in siliceous rocks can be found (Szczerban and Urbani, 1974).

Taking into account the criteria adopted in this work, the solution of silica has to be considered a parakarstic phenomenon at $\mathrm{pH}$ below 9 , while it enters the karstic domain only when the $\mathrm{pH}$ should become very alkaline. 